\title{
Effect of Gonadal Hormones on Neurotransmitters Implicated in the Pathophysiology of Obsessive- Compulsive Disorder: A Critical Review
}

\author{
Marta Karpinski ${ }^{a, b} \quad$ Gabriella Francesca Mattinab, c Meir Steiner ${ }^{b-d}$ \\ ${ }^{a}$ Faculty of Health Sciences, McMaster University, ${ }^{b}$ Women's Health Concerns Clinic, St. Joseph's Healthcare, \\ 'MiNDS Neuroscience, McMaster University, and d Psychiatry and Behavioural Neurosciences, St. Joseph's Healthcare, \\ Hamilton, ON, Canada
}

\section{Keywords}

Obsessive-compulsive disorder - Female reproduction . Serotonin · Dopamine · Glutamate · Gonadal hormones

\begin{abstract}
Obsessive-compulsive disorder (OCD) is a relatively common neuropsychiatric disorder affecting between 1.6 and $3.2 \%$ of the population. A number of studies have previously reported increased incidence of OCD, or exacerbation of preexisting symptoms in females during reproductive events. Since these periods are known to involve fluctuating levels of gonadal hormones, these steroids have been suggested to be involved in modulating the course of the disorder. However, to date, only a few studies have measured hormone levels and obsessive-compulsive (OC) symptoms concurrently; thus, direct evidence for this relationship is limited. In turn, investigations into neurotransmission in $\mathrm{OC}$ individuals have been more extensive, and have implicated the serotonergic, dopaminergic, and glutamatergic neurotransmitter systems in OCD pathology. There is evidence suggesting that reproductive hormones estrogens and progesterone can modulate neurotransmission in the aforementioned signaling pathways by regulating the expression of recep-
\end{abstract}

\section{KARGER}

(C) 2016 S. Karger AG, Basel

E-Mail karger@karger.com

www.karger.com/nen tors and channels, as well as the synthesis and release of the neurotransmitter itself. Overall, estrogen and progesterone appear to enhance serotonin signaling, which has been associated with improved OC symptoms. The effect of the gonadal hormones in dopaminergic and glutamatergic signaling is much more variable, highlighting the need for further research in this field. The existing evidence shows that gonadal hormones can have profound impacts on neurotransmission in the brain, leading to the conclusion that the hormonal fluctuations during reproductive events are a plausible factor contributing to the change in OCD course during these times.

(c) 2016 S. Karger AG, Basel

\section{Introduction}

Obsessive-compulsive disorder (OCD) is a debilitating neuropsychiatric disorder characterized by the presence of obsessions and compulsions. Obsessions are recurrent, persistent, and unwanted thoughts, urges, or images that cause anxiety. In response to these obsessions, the individual develops compulsions - repetitive behaviors, or mental acts that make a futile attempt to reduce

Meir Steiner, MD, MSc, PhD, FRCPC

Psychiatry and Behavioural Neurosciences McMaster University and St. Joseph's Healthcare 100 West 5th Street, Hamilton, ON L8N 3K7 (Canada)

E-Mail mst@mcmaster.ca 
distress, or prevent some dreaded event. The specific obsessions and compulsions vary among individuals; however, they commonly revolve around themes of cleaning, symmetry, taboo thoughts, and harm. These behaviors consume significant amounts of time, and have debilitating consequences on social and occupational functioning [1]. OCD has a lifetime prevalence rate of 1.6-3.2\%, making it a relatively common psychiatric disorder [2].

Although the exact etiology of OCD remains elusive at this point in time, there is strong speculation that both genetic and environmental factors are involved. Genetic variations in the receptor and enzyme components of the serotonergic, dopaminergic, and glutamatergic neurotransmitter systems, as well genetic variations in growth and transcription factors have been associated with OCD [3]. These gene variations may increase susceptibility of individuals to $O C D$ at various life events.

It has been observed that in some cases, obsessivecompulsive (OC) symptoms worsen or first appear during reproductive milestones such as pregnancy, and the postpartum period [4-6]. A 2013 meta-analysis revealed that pregnant and postpartum women had a 45 and $138 \%$ increased risk of developing OCD, respectively [7]. It has been proposed that the hormonal changes associated with these reproductive events may be involved in modulating the course of OCD in these patients.

Existing literature provides only weak evidence to confirm the role of gonadal steroids in OCD pathology. To date, no study has concurrently measured hormone levels and OCD symptoms, making it difficult to derive sound conclusions about this relationship. To our knowledge, only 1 human study by Avgoustinaki et al. [8] measured both circulating levels of gonadal steroids and psychometric parameters to characterize the relationship between reproductive events and OC symptoms in a healthy population. In this study, researchers found only a marginally significant association between progesterone levels and scores on the 7-point scale of the Minnesota Multiphasic Personality Inventory [8].

Evidence from preclinical animal studies has suggested an inverse relationship between estradiol levels and OCD severity. Fernández-Guasti et al. [9] observed the effects of estradiol using the 8-hydroxy-2-(di-n-propylamino)-tetralin hydrobromide (8-OH-DPAT) model of OCD. Administration of 8-OH-DPAT decreases the number of times rats spontaneously choose different arms in a $\mathrm{T}$ maze (i.e., increases frequency of repetitive behaviors) [10]. Fernández-Guasti et al. [9] showed that administration of estradiol reduced the preservative effects of 8-OH-DPAT. In a different study, administration
Table 1. Keywords for database search

\begin{tabular}{lllll}
\hline 1 & Serotonin & Dopamine & Glutamate & Oxytocin \\
\hline $\begin{array}{l}\text { 2 AND } \\
\text { (one of) }\end{array}$ & $\begin{array}{l}\text { Estrogen } \\
\text { Progesterone } \\
\text { Oxytocin }\end{array}$ & $\begin{array}{l}\text { Estrogen } \\
\text { Progesterone } \\
\text { Oxytocin }\end{array}$ & $\begin{array}{l}\text { Estrogen } \\
\text { Progesterone } \\
\text { Oxytocin }\end{array}$ & OCD \\
\hline AND & OCD & OCD & OCD & \\
(one of) & Tryptophan & Tyrosine & Glutamate & \\
& hydroxylase & hydroxylase & release & \\
& MAO & DA release & NMDA & \\
MAO-A & DAT & AMPA & \\
& SERT & D1 & mGlu & \\
5-HT receptor & D2 & EAAT & \\
Synaptic & D3 & Synaptic & \\
proteins & D4 & proteins & \\
& D5 & & \\
& Synaptic & \\
& proteins & \\
& & &
\end{tabular}

of estradiol to prepubertal female rats decreased leverpressing, while estradiol withdrawal, similar to the rapid decline in estradiol in postpartum, restored lever-pressing behaviors [11].

The regulation of OC symptoms by reproductive hormones is thought to be mediated by 3 neurotransmitter systems: the serotonergic, dopaminergic, and glutamatergic systems. Generally, impaired serotonergic signaling, and enhanced neurotransmission by dopamine and glutamate have been associated with worsened OCD [12, 13]. These neurotransmitter systems can be modified by hormones including estrogens, progesterone, and oxytocin, and are speculated to be the link between fluctuating hormone levels and altered OCD course during reproductive events.

In the currently existing literature, there appears to be a lack of high-quality evidence from prospective cohort studies assessing OC tendencies along the course of hormone level fluctuations in females. This research gap is partially justified by the difficulty in recruiting and retaining a large sample, and a general aversion to invasive procedures such as blood tests which are necessary for hormone level measurements. Nevertheless, collection of this type of data is necessary to better characterize the relationship between OC symptoms and hormonal changes during female reproductive milestones.

Since clinical studies reporting concurrent measurements of hormone levels and OC symptoms have been sparse, the significance of hormones in OCD course is not conclusively known at this point in time. However, based on the findings reported in the existing literature, this
2
Neuroendocrinology 2017;105:1-16 DOI: $10.1159 / 000453664$
Karpinski/Mattina/Steiner 
does appear to be a relationship that warrants further investigation. In order to delineate the relationship between reproductive events and OCD, this article will summarize what is currently known about the effect of gonadal hormones on the neurotransmitter systems implicated in OCD pathology.

\section{Methodology}

The present study is a critical review of the literature, examining what is currently known about the effect of reproductive hormones on the neurotransmitter systems implicated in OCD. PubMed, PsychINFO, and OVID were searched for relevant literature. The combinations of keywords used for the searches are presented in Table 1. Reference lists were reviewed for other relevant publications. Articles published in English were retrieved, and no date restrictions were placed.

\section{Neurotransmitter Systems in OCD}

\section{Serotonin}

Serotonin in OCD

The serotonergic system was first implicated in the pathogenesis of OC symptoms by results from pharmacological studies. Early findings revealed that OC symptoms were alleviated with the administration of the tricyclic antidepressant clomipramine, which is a potent serotonin reuptake inhibitor (SRI) [12]. Other studies have shown that serotonin reuptake agonist metachlorophenyl-piperazine worsened OC symptoms in some patients [14]. This suggests that patients with OCD, or those demonstrating OC symptoms, might have a dysregulation inhibiting sustained serotonin release and/or signaling. Subsequent studies with selective SRIs (SSRIs) such as fluoxetine, paroxetine, sertraline, citalopram, and escitalopram showed comparable effects to treatment with clomipramine [15].

Later studies used more specific physiological measures to confirm the role of serotonin in OCD. The serotonin metabolite 5-hydroxyindoleacetic acid was found to be significantly higher in the cerebrospinal fluid (CSF) of patients with OC symptoms compared to healthy volunteers, suggesting increased brain serotonin turnover, although these results have not always been consistent $[12,16]$.

Other studies have used single-photon emission computed tomography to measure the availability of serotonin reuptake transporter (SERT) in small samples of OCD patients. Results from this research have been

Hormones and Neurotransmitters in

OCD
Table 2. Effect of gonadal hormones on the serotonergic system and OCD symptoms

\begin{tabular}{|c|c|c|c|}
\hline Hormone & $\begin{array}{l}\text { Effect on } \\
\text { serotonergic } \\
\text { system }\end{array}$ & $\begin{array}{l}\text { Overall } \\
\text { effect }\end{array}$ & $\begin{array}{l}\text { Theorized } \\
\text { consequence on } \\
\text { OCD }\end{array}$ \\
\hline \multirow[t]{2}{*}{ Estradiol } & $\begin{array}{l}\uparrow \mathrm{TPH} \\
\downarrow \mathrm{MAO}-\mathrm{A} \\
\downarrow 5-\mathrm{HT}_{1 \mathrm{~A}} \\
\downarrow 5-\mathrm{HT}_{1 \mathrm{~B}} \\
\uparrow 5-\mathrm{HT}_{2 \mathrm{~A}} \\
\uparrow \text { synapse } \\
\text { assembly }\end{array}$ & $\begin{array}{l}\uparrow \text { serotonin } \\
\text { signaling }\end{array}$ & $\begin{array}{l}\text { improved OCD } \\
\text { symptoms }\end{array}$ \\
\hline & $\uparrow / \downarrow$ SERT & $\begin{array}{l}\text { unknown } \\
\text { effect on } \\
\text { serotonin } \\
\text { signaling }\end{array}$ & $\begin{array}{l}\text { unknown effect } \\
\text { on OCD } \\
\text { symptoms }\end{array}$ \\
\hline Progesterone & $\begin{array}{l}\uparrow \mathrm{TPH} \\
\downarrow \mathrm{MAO}-\mathrm{A} \\
\downarrow 5-\mathrm{HT}_{1 \mathrm{~A}} \\
\uparrow 5-\mathrm{HT}_{2 \mathrm{~A}}\end{array}$ & $\begin{array}{l}\uparrow \text { serotonin } \\
\text { signaling }\end{array}$ & $\begin{array}{l}\text { improved OCD } \\
\text { symptoms }\end{array}$ \\
\hline
\end{tabular}

mixed, showing reduced, increased, and unchanged SERT availability in OCD patients [17-22].

Estradiol and Serotonin

Evidence from the literature points to 4 major effects of estradiol on the serotonergic system: increased serotonin synthesis, decreased serotonin breakdown, modulation of serotonin receptors, and increased synapse assembly $[23,24]$. Estradiol does not appear to have a significant effect on the amount of serotonergic neurons in the central nervous system [25].

The ultimate effect of this neuromodulation by estradiol is an increase in serotonin release, and sustained serotonin neurotransmission, which is indicative of an overall protective effect against OCD. Effects of estradiol on the serotonergic system and the presumed implications for OCD are summarized in Table 2.

(1) Evidence for increased serotonin synthesis

Estradiol increases serotonin synthesis through an upregulation of tryptophan hydroxylase $(\mathrm{TPH})$ - the protein responsible for catalyzing the rate-limiting step in the serotonin synthesis pathway. Previous animal studies have demonstrated increased TPH mRNA levels in the dorsal raphe nuclei and trigeminal ganglia $[26,27]$. Estradiol was later found to specifically increase TPH2 (an isoform exclusively expressed in the central nervous system) mRNA in the dorsal raphe nucleus in macaques and rats [28]. These associations are confirmed by evidence from

Neuroendocrinology 2017;105:1-16 DOI: $10.1159 / 000453664$ 
protein expression studies measuring TPH protein mass in ovariectomized (OVX) animals, unable to endogenously produce estradiol. It was found that OVX guinea pigs and macaques treated with estradiol for 28 days had significantly higher TPH protein mass than the untreated OVX controls $[29,30]$. Although not examined in these studies, the increase in serotonin levels as seen in estradiol-treated animals should theoretically lead to the amelioration of OC symptoms. To our knowledge, there has been no investigation into hormone-regulated TPH expression in human subjects.

(2) Evidence for decreased serotonin breakdown

Estradiol decreases serotonin breakdown by inhibiting the activity of monoamine oxidase A (MAO-A) - the enzyme that degrades serotonin into the inactive 5-hydroxyindoleacetic acid metabolite [31]. Administration of estradiol to OVX rats over the course of 1-4 weeks resulted in a $30 \%$ decrease in MAO-A activity in the basomedial hypothalamus and corticomedial amygdala, as measured by a radiochemical assay [32]. Similar results were reported in estradiol-treated macaques and rats in various parts of the brain $[30,33,34]$. Despite the decrease in MAO-A after a month of estradiol treatment in the study by Smith et al. [30], the researchers interestingly noted that after 5 months of estradiol administration, MAO-A levels were no different from OVX controls. It was proposed that long-term estradiol treatment increases extracellular serotonin levels to concentrations high enough to induce a negative feedback loop to stimulate MAO-A production, and therefore serotonin metabolism in an effort to maintain homeostasis [30]. This is an important finding as it relates to the human menstrual cycle, where a woman is on a 28 -day cycle of transient increases and drops in reproductive hormone levels rather than prolonged periods of stable steroid activity. Around day 22, estrogen levels drop significantly, and the subsequent days before menstruation have been associated with significant exacerbation of OC symptoms in as many as $49 \%$ of women in one study [35]. Women on birth control present an interesting case, as the pills are taken to stabilize hormone levels, which possibly leads to the inadvertent induction of feedback loops to regulate neurotransmitter levels, similar to the phenomenon observed by Smith et al. [30]. To our knowledge, there has been no investigation into the effect of hormonal contraceptives on OCD severity; however, they have been associated with other psychiatric disorders including depression [36].

To date, only a limited number of studies testing the relationship between estradiol and MAO activity have been conducted in human subjects. A study by Sacher et al. [37] used carbon 11-labeled harmine positron emission tomography (PET) to measure MAO-A binding (a surrogate measure of MAO-A activity) in postpartum. Compared to controls, MAO-A distribution was found to be $43 \%$ higher in 4 - to 6 -day postpartum women, who may experience up to a 1,000-fold drop in estradiol levels during this time [37]. A methodologically similar study conducted in perimenopausal women, found MAO-A distribution to be 34 and $16 \%$ higher in perimenopausal women compared to women of reproductive age, and those undergoing menopause, respectively [38]. Perimenopause is associated with estradiol level fluctuations, with episodes of significant estradiol level decline, and as such is correlated with increased MAO-A density [38]. Increased MAO-A density associated with decreased estradiol may help explain the onset or worsening of OCD during reproductive events.

(3) Evidence for modulation of serotonin transporters and receptors

A substantial amount of evidence has also implicated estradiol in the modulation of a number of different serotonin transporters and receptors.

Estradiol administration has been shown to have variable effects on SERT - the protein involved in reuptake of serotonin from the synaptic cleft. In studies of acute estradiol exposure in rats, SERT proteins were shown to be upregulated in both the raphe nuclei and the hypothalamus $[39,40]$. In contrast, chronic estradiol administration in macaques was associated with decreased levels of SERT in the raphe nuclei [41] and increased SERT activity in the basal ganglia and hypothalamic nuclei in several animal studies [30, 42]. Yet still, other studies found that treatment with estradiol in OVX macaques either increased or did not change SERT binding in various brain regions, and did not change SERT binding in rats [43].

Data from human studies have demonstrated a higher degree of consistency. A recent clinical investigation found that after a treatment period of 18 days, subjects treated with gonadotropin-releasing hormone, which is intended to model ovarian sex hormone fluctuation, demonstrated significantly higher depressive symptoms, which were positively associated with decreased estradiol levels, and increased neocortical SERT binding [44]. Other recent studies in transsexual and postmenopausal patient cohorts report an inverse association between estradiol levels and SERT activity - increasing estradiol results in a downregulation of SERT $[45,46]$.

Estradiol administration has generally been shown to downregulate expression of the $5-\mathrm{HT}_{1 \mathrm{~A}}$ and $5-\mathrm{HT}_{1 \mathrm{~B}}$ re-
4

Neuroendocrinology 2017;105:1-16 DOI: $10.1159 / 000453664$
Karpinski/Mattina/Steiner 
ceptors in a region-specific manner. The $5-\mathrm{HT}_{1 \mathrm{~A}}$ and $5-\mathrm{HT}_{1 \mathrm{~B}}$ receptors are autoreceptors that have an inhibitory role over serotonergic transmission, and have been implicated in many anxiety disorders $[31,47]$. The majority of research in OVX animals has consistently reported a downregulation of $5-\mathrm{HT}_{1 \mathrm{~A}}$ mRNA expression and/or protein binding in various brain regions $[48,49]$. Estradiol has also been suggested to desensitize signaling via the $5-\mathrm{HT}_{1 \mathrm{~A}}$ receptor in the paraventricular nucleus [50]. Other studies have found no significant change in $5-\mathrm{HT}_{1 \mathrm{~A}}$ mRNA levels in the rat dorsal raphe nuclei, and instead only report a decrease in the $5-\mathrm{HT}_{1 \mathrm{~B}}$ autoreceptor subtype [51]. Levels of $5-\mathrm{HT}_{1 \mathrm{~A}}$ in estradiol-treated postmenopausal women also appeared unchanged [52].

In contrast, the $5-\mathrm{HT}_{2 \mathrm{~A}}$ receptor was shown to increase in density with the administration of estradiol. The $5-\mathrm{HT}_{2 \mathrm{~A}}$ receptors mediate serotonergic signaling, and are found on both pre- and postsynaptic neurons, as well as on other nonserotonergic neurons, for example those involved in dopamine signaling [53]. A study examining $5-\mathrm{HT}_{2 \mathrm{~A}}$ density after estradiol treatment in OVX rats, found a significant increase in the raphe nuclei and forebrain [54]. Binding to $5-\mathrm{HT}_{2 \mathrm{~A}}$ was also increased in the frontal cortex and striatum of estradiol-treated macaques [49]. In studies of human patients on hormone replacement therapy, PET scans revealed increased $5-\mathrm{HT}_{2 \mathrm{~A}}$ levels in the prefrontal cortex, anterior cingulate cortex (ACC), frontal gyrus, and cerebral regions $[55,56]$. Another study found downregulation of $5-\mathrm{HT}_{2 \mathrm{~A}}$ receptors in long-term estradiol therapy users, and this was characterized as a compensatory mechanism for increased synaptic serotonin supposedly induced by estradiol [57]. The evidence suggests estradiol increases serotonin signaling through an upregulation of serotonin receptors and downregulation of autoreceptors which is hypothesized to improve OCD symptoms.

(4) Evidence for increased synapse assembly

A study by Bethea and Reddy [23] investigated the effects of estradiol and progesterone on the gene expression of proteins involved in the assembly of synapses. These effects were studied in serotonergic neurons of OVX rhesus macaques treated with placebo, estradiol, or an estradiol-progesterone combination. It was found that estradiol treatment increased expression of genes coding for synapse molecules such as ephrin receptor A4, cadherin 11 , neurexin 3 , integrin $A 8$, and neural cell adhesion molecule, compared to placebo. The progesterone in the combination treatment appeared to suppress the estradiol-induced increase in gene expression [23].

Hormones and Neurotransmitters in OCD
Progesterone and Serotonin

Investigation into the effects of progesterone on serotonin neurotransmission has been more limited. Effects of progesterone on serotonin neurotransmission and its presumed effects on OCD symptoms are summarized in Table 2.

A study by Lu et al. [58] explored the effects of estradiol and progesterone on the TPH enzyme. It was found that in the hypothalamus of OVX rats, treatment with estradiol and progesterone resulted in levels of the TPH enzyme similar to those in rats treated with estradiol alone. However, treatment with estradiol and progesterone, but not estradiol alone, significantly increased serotonin levels. The authors suggest that this discrepancy is due to the absence of nuclear progesterone receptors in serotonergic neurons, thereby limiting progesterone's influence over TPH levels. Progesterone's effect on serotonin concentrations themselves is thought to be modulated by a nonnuclear receptor mechanism [58]. Other studies reported that progesterone alone was in fact sufficient to increase TPH protein levels in the dorsal raphe nuclei $[28,29]$. Further conflicting results reported a decrease in serotonergic activity after the administration of progesterone in rats [59].

Progesterone has not been shown to significantly alter SERT expression, as no significant difference in SERT levels was detected between groups treated with estradiol and progesterone, and estradiol alone $[41,60]$. On the other hand, there is evidence suggesting progesterone treatment significantly decreases MAO-A levels in various brain regions in animal models $[61,62]$. Downregulation of the $5-\mathrm{HT}_{1 \mathrm{~A}}$ autoreceptor has also been reported after treatment with progesterone [60, 63]. In contrast, increasing progesterone dose in conjunction with estradiol treatment results in increased mRNA expression of 5- $\mathrm{HT}_{2 \mathrm{~A}}$ in the ventral hippocampus [64]. Thus, like estradiol, progesterone appears to increase serotonin signaling, which may be neuroprotective against OCD.

Although numerous studies have demonstrated the effectiveness of SRIs as a primary treatment option for OCD, there appears to be a subset of OCD patients that are resistant to SRI treatment [65]. Furthermore, pharmacological challenge studies of the serotonin system, as well as studies measuring serotonin metabolite levels in the CSF have not always shown consistent results [66]. This points to the possibility of the involvement of other neurochemical systems in OCD pathology.

Neuroendocrinology 2017;105:1-16 DOI: $10.1159 / 000453664$ 
Fig. 1. Downstream interactions of the 3 neurotransmitter systems involved in OCD. In the event of low serotonin levels, possibly occurring as a consequence of low estradiol, the quantities of serotonin are insufficient to inhibit dopamine signaling via $5-\mathrm{HT}_{2 \mathrm{~A}}$ receptors. This results in increased dopaminergic tone, which has also been identified in some OCD patients. Increased dopaminergic signals from the substantia nigra pars compacta to the striatum, mediated by $\mathrm{D} 1$ receptors, increase GABA release from the striatum to the globus pallidus internal and substantia nigra reticulata, thus skewing the cortico-striato-thalamocortical loop towards the direct pathway.

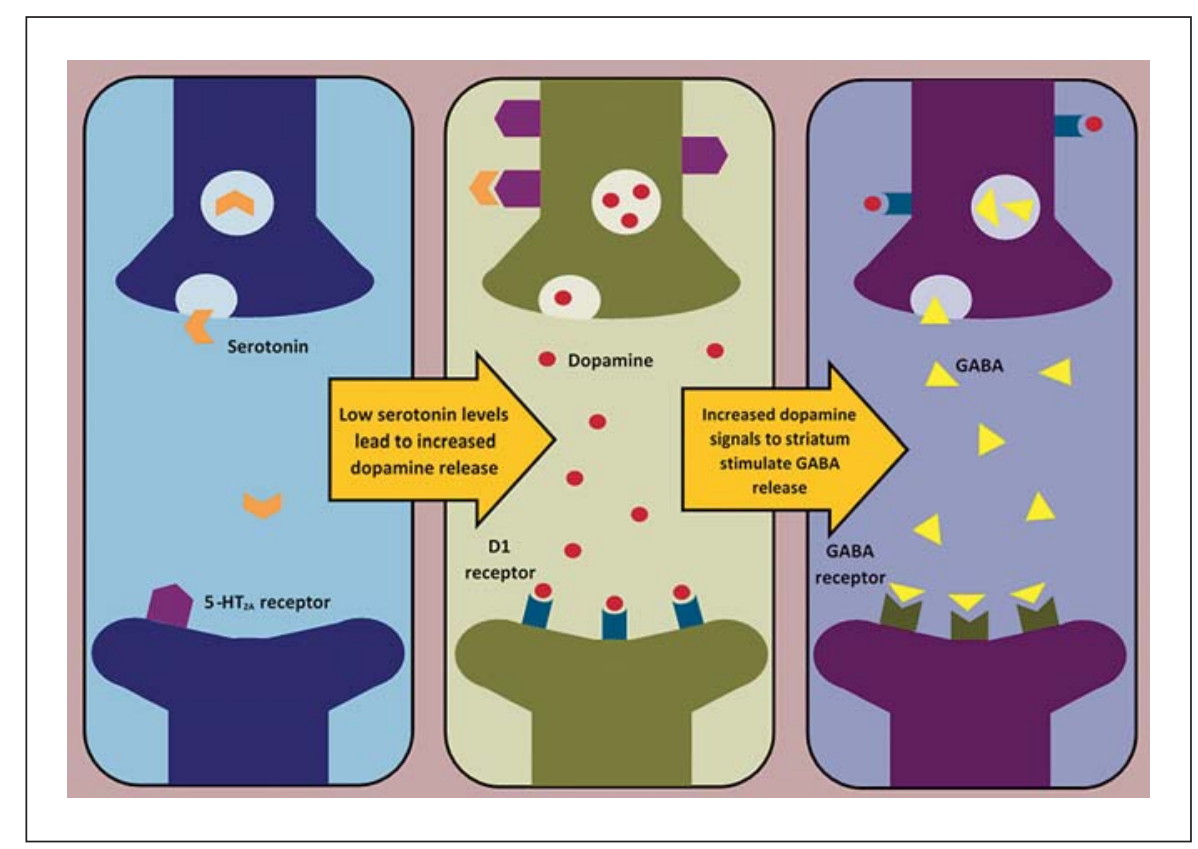

\section{Dopamine}

\section{Dopamine in OCD}

The neurotransmitter dopamine has also been implicated in OCD pathology. Studies have demonstrated that administration of dopamine agonists leads to an exacerbation of OC symptoms, while dopamine blockers have been effectively used in treatment of some OCD spectrum disorders including Tourette's syndrome [12, 67]. Administration of the dopamine D2/D3 receptor agonist quinpirole has been shown to increase compulsive checking in rat models of OCD $[68,69]$.

Treatment with the SSRI fluvoxamine, increased D2 receptor binding, and was accompanied by an improvement in symptoms [70]. It was suggested that this modification of D2 receptor availability is a result of fluvoxamine's modulation of the serotonergic system. Serotonergic neurons projecting from the raphe nuclei are thought to modulate the cortico-striato-thalamo-cortical (CSTC) loop that is associated with OCD, in which dopamine is the dominant neurotransmitter [65]. When serotonin is released from a presynaptic neuron, it may bind to $5-\mathrm{HT}_{2 \mathrm{~A}}$ receptors on the somatodendritic surface of dopamine neurons. This interaction has an inhibitory effect on the dopamine neuron, which will reduce the release of dopamine into the synaptic cleft and consequently prevent further downstream dopamine signaling [71]. In the presence of an SSRI, there will be sustained serotonin signaling, resulting in a prolonged inhibitory effect on the dopaminergic system. Conversely, in the absence of serotonin, or in the presence of a $5-\mathrm{HT}_{2 \mathrm{~A}}$ antagonist or $5-\mathrm{HT}_{1 \mathrm{~A}}$ autoreceptor agonist, the dopamine neuron may release its neurotransmitter to activate a dopamine signaling cascade (Fig. 1) [71]. As previously discussed, since OCD patients are thought to have impaired serotonin signaling, it is possible that this deficiency is leading to dopaminergic hyperactivity, characteristic of OCD [65].

When research revealed that there is some modulation of the dopaminergic system by serotonin, investigators proposed that concomitant use of SSRIs and dopaminergic antagonists may be an effective option for SSRI treatment-refractory patients $[65,71]$. Indeed, co-administration of the 2 drugs appeared to be quite efficacious in a number of trials, including an open trial by Metin's group that showed a significant improvement in $95 \%$ of the patients treated with an SSRI and amisulpiride $[72,73]$.

A number of studies have also aimed to characterize dysregulations of the dopaminergic system in OCD patients through in vivo brain scans. Olver et al. $[74,75]$ used PET scans to assess binding of $\left[{ }^{11} \mathrm{C}\right]-\mathrm{SCH} 23390$, a dopamine D1 antagonist ligand, to the dopamine D1 receptor in untreated OCD patients. Receptor binding was found to be reduced in the caudate nucleus, putamen, and the ACC. This decreased D1 binding is thought to reflect a downregulation of $\mathrm{D} 1$ receptors as a compensatory mechanism for the increased dopaminergic drive from the substantia nigra pars compacta $(\mathrm{SNc})$. This in- 
Fig. 2. The cortico-striato-thalamo-cortical circuit in OCD. In OCD, increased glutamatergic signaling from the orbitofrontal cortex (OFC) and anterior cingulate cortex (ACC) is thought to increase striatal inhibitory action on globus pallidus internal (GPi) and substantia nigra reticulata $(\mathrm{SNr})$, ultimately reducing inhibition of the thalamus, which will continue increasing glutamate signaling to the OFC/ACC in a positive-feedback loop. Alternatively, a striatal defect decreases inhibition of globus pallidus external (GPe), which will increase subthalamic nucleus (STN) inhibition and decrease GPi/SNr excitation. In OCD, the balance between the direct and indirect pathways is skewed towards the former. Adapted from Pauls et al. [119].

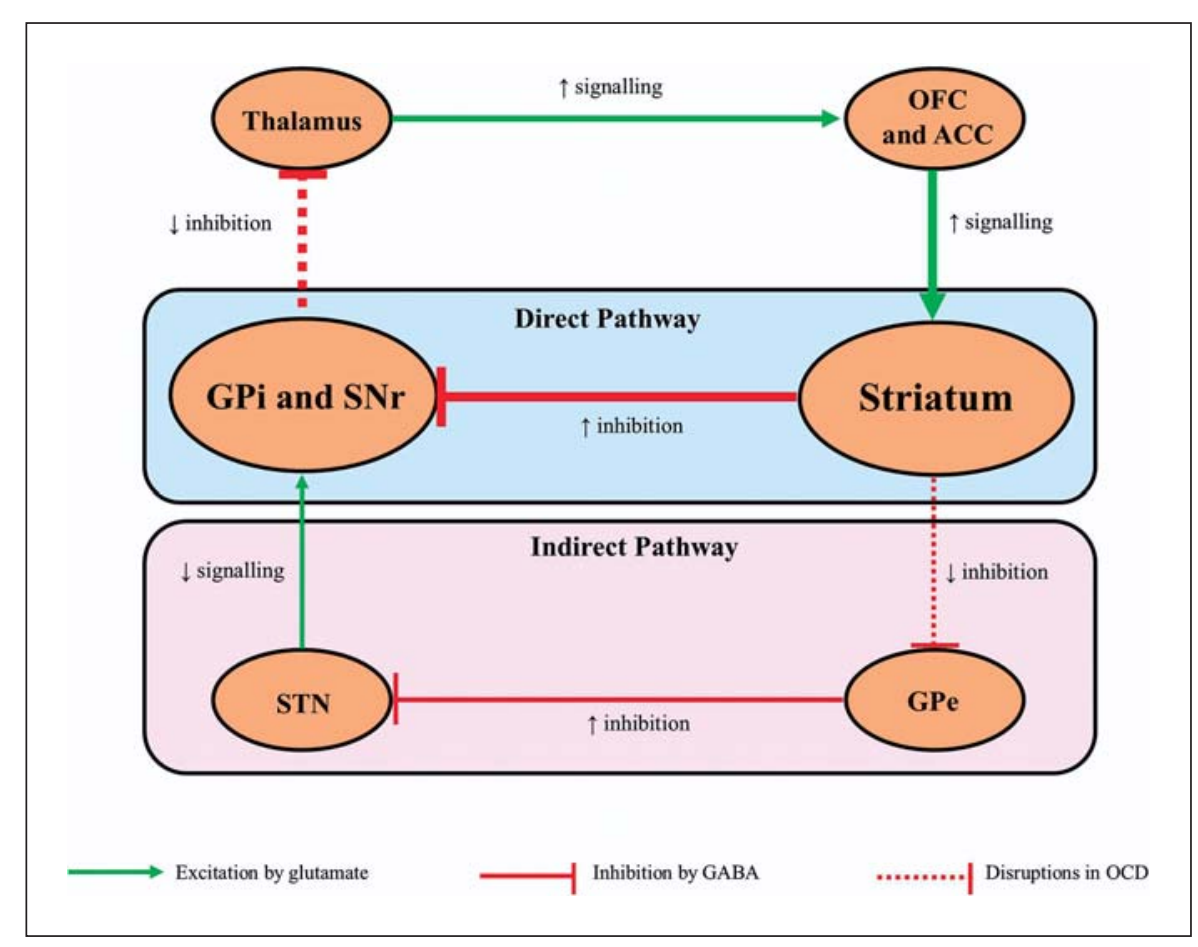

creased dopaminergic activity from the $\mathrm{SNc}$ is thought to create an imbalance in the CSTC loop (Fig. 1, 2) [74]. It is suggested that in OCD there is increased stimulation of the ACC from the ventral tegmental area via D1 receptors [75]. Increased activation of the ACC has been previously shown to create a sense that something is 'not right' and may drive obsessions and compulsions in OCD patients [76]. Similar experiments have been performed to study D2 function, and demonstrated similar trends - reduced D2 receptor binding in the striatum $[77,78]$.

There has also been some investigation into the potential role of the dopamine transporter (DAT) in OCD. One study found higher DAT densities in the left basal ganglia of OCD patients, measured using $\left[{ }^{123} \mathrm{I}\right] \beta$-CIT binding ratios and single-photon emission computed tomography [79]. The researchers propose the increase in DAT density may be due to an inherent abnormality of the transporter itself, or may be a negative feedback mechanism in response to increased dopaminergic tone; the exact cause of this phenomenon is yet to be elucidated. In OCD patients treated with the SSRI citalopram, one study reported a $40 \%$ increase in DAT availability, which is thought to be a consequence of decreased synaptic dopamine levels due to the previously discussed serotonin-dopamine interactions [80].

Hormones and Neurotransmitters in OCD
Estradiol and Dopamine

Early studies have shown that neurotransmission by the dopaminergic system changes at various points of the menstrual cycle, suggesting a possible role of the gonadal hormones in modulating the neurosignaling pathway [81]. Existing literature suggests that estradiol modulates dopaminergic signaling through variations in tyrosine hydroxylase activity, dopamine release, and DAT and receptor expression [82]. This evidence is summarized in Table 3.

(1) Evidence for increased tyrosine hydroxylase activity

To date, only 2 studies investigating the effect of estrogens on tyrosine hydroxylase in OVX animals have been conducted. Estradiol was found to increase tyrosine hydroxylase immunoreactive neurons in the substantia nigra of rats, while in macaques, this effect was observed in the caudate nucleus and putamen $[83,84]$.

(2) Evidence for increased dopamine release

Estradiol has been found to increase dopamine release in the caudate-putamen and in the nucleus accumbens [85]. Estrogens are thought to be capable of interacting with dopaminergic neurons directly to downregulate D2 autoreceptors, as well as indirectly by inhibiting GABAergic neurons which have recurrent collaterals onto dopamine terminals [85]. In animal studies, ovariectomy

Neuroendocrinology 2017;105:1-16 DOI: $10.1159 / 000453664$ 
Table 3. Effect of gonadal hormones on the dopaminergic system and OCD symptoms

\begin{tabular}{|c|c|c|c|}
\hline Hormone & $\begin{array}{l}\text { Effect on } \\
\text { dopaminergic } \\
\text { system }\end{array}$ & $\begin{array}{l}\text { Overall } \\
\text { effect }\end{array}$ & $\begin{array}{l}\text { Theorized } \\
\text { consequence on } \\
\text { OCD }\end{array}$ \\
\hline \multirow[t]{3}{*}{ Estradiol } & $\begin{array}{l}\uparrow \mathrm{TH} \\
\uparrow \mathrm{DA} \text { release } \\
\uparrow \mathrm{D} 1\end{array}$ & $\begin{array}{l}\uparrow \text { dopamine } \\
\text { signaling }\end{array}$ & $\begin{array}{l}\text { worsened OCD } \\
\text { symptoms }\end{array}$ \\
\hline & $\downarrow \mathrm{D} 3$ & $\begin{array}{l}\downarrow \text { dopamine } \\
\text { signaling }\end{array}$ & $\begin{array}{l}\text { improved OCD } \\
\text { symptoms }\end{array}$ \\
\hline & $\begin{array}{l}\text { unclear effect on } \\
\text { DAT and D2 }\end{array}$ & $\begin{array}{l}\text { unknown } \\
\text { effect on } \\
\text { dopamine } \\
\text { signaling }\end{array}$ & $\begin{array}{l}\text { unknown effect } \\
\text { on OCD } \\
\text { symptoms }\end{array}$ \\
\hline \multirow[t]{2}{*}{ Progesterone } & $\uparrow \mathrm{TH}$ & $\begin{array}{l}\uparrow \text { dopamine } \\
\text { signaling }\end{array}$ & $\begin{array}{l}\text { worsened OCD } \\
\text { symptoms }\end{array}$ \\
\hline & $\begin{array}{l}\text { unclear effect on } \\
\text { DA release, DAT } \\
\text { and D2 }\end{array}$ & $\begin{array}{l}\text { unknown } \\
\text { effect on } \\
\text { dopamine } \\
\text { signaling }\end{array}$ & $\begin{array}{l}\text { unknown effect } \\
\text { on OCD } \\
\text { symptoms }\end{array}$ \\
\hline
\end{tabular}

was found to decrease dopamine release which was reversed with subsequent estradiol treatment [86, 87].

(3) Dopamine transporter

The expression of DAT fluctuates at the various stages of the menstrual cycle [81]. Ovariectomy in rats has been shown to decrease DAT density [88]. However, upon administration of estradiol treatment, these effects were shown to be corrected [89]. A study in postmenopausal women similarly found that estradiol replacement therapy produced an increase in DAT density in the left anterior putamen [90]. However, this effect seems to be region-specific as no such renewal of DAT levels was observed in the substantia nigra, amygdala, hypothalamus, midbrain, nucleus accumbens, ventral tegmental area, or in the striatum as reported by other animal studies [88, 91]. Yet still, conflicting evidence was reported by another study which found that ovariectomy increased DAT in the striatum, and subsequent estradiol treatment reduced levels back to normal [92].

(4) Dopamine receptors

Expression of D1 receptors in the striatum is thought to be modulated by gonadal hormones as evidenced by fluctuations in receptor density during the menstrual cycle [93]. Ovariectomy was associated with decreased D1 receptor density, but this effect was reversed with chronic estradiol treatment [94-97].

Evidence for the effect of estrogen on D2 receptors has been conflicting. One study reported increased D2 den- sity in the nucleus accumbens and caudate nucleus of OVX rats, which was attenuated with estradiol treatment [43]. Estradiol has also been shown to induce a shift of D2 receptors from high- to low-affinity states [98]. Others have reported the opposite, with estradiol increasing D2 density in the striatum of OVX rats $[81,99]$. In a human study, no changes in D2 receptor density were detected by PET scans at different phases of the menstrual cycle [100].

Although ovariectomy appeared to have no significant effects on D3 receptor binding, treatment with estradiol decreased receptor binding in the island of Calleja, the nucleus accumbens, and the anterior striatum [99]. The effect of the gonadal hormones on the D4 and D5 receptors has not been well characterized.

At this point in time, it is difficult to draw conclusions about estradiol's overall effect on dopaminergic signaling. Estradiol treatment in animal models appears to increase dopamine synthesis and release, which would suggest that periods of elevated estradiol could lead to worsening of OC symptoms. This is inconsistent with the current understanding of the serotonin-dopamine interactions, in which elevated serotonin, presumably occurring in relation to high estradiol levels, inhibits dopamine release. Further research is needed to better characterize these relationships in the context of OCD.

\section{Progesterone and Dopamine}

Studies examining modulation of dopaminergic activity by progesterone have been more limited in number. Effects of progesterone on dopamine neurotransmission are summarized in Table 3.

Physiological doses of progesterone were found to increase release of dopamine in the striatum of OVX rats $[101,102]$. In contrast, in other studies, progesterone did not appear to have a significant effect on dopamine release in OVX rats that had not been pretreated with estradiol [103]. This suggested that estradiol is necessary in the mechanism of neuromodulation by progesterone. One study also found an increase in tyrosine hydroxylase immunoreactive neurons in the caudate nucleus and putamen after progesterone treatment of OVX macaques [84].

The dopamine receptors are also under the influence of progesterone. In the striatum and substantia nigra, DAT density increases with chronic progesterone treatment with a pharmacological dose [104]. Others reported no such effect in either rats treated with acute or chronic progesterone treatment $[92,105]$. With regard to the D2
8
Neuroendocrinology 2017;105:1-16 DOI: $10.1159 / 000453664$
Karpinski/Mattina/Steiner 
receptor, acute but not chronic progesterone treatment decreased binding density $[106,107]$.

As with the estrogen-dopamine relationship, the effects of progesterone on the dopaminergic system are variable with some components being upregulated, while others are inhibited. As such, it is difficult to draw conclusions about the role of this relationship in OCD. Dysregulated dopamine signaling can have additional consequences on signaling in the CSTC loop, leading to further dysregulation of the glutamate neurotransmitter system.

\section{Glutamate}

Glutamate in OCD

The first line of evidence suggesting the involvement of glutamate in OC etiology comes from examination of CSF samples. To date, 2 studies have been conducted to measure the levels of glutamate in the CSF of untreated OCD patients. Both have found significantly higher glutamate levels in the CSF of OCD patients compared to controls $[108,109]$. Evidence from magnetic resonance spectroscopy studies used to measure glutamate brain concentrations in OCD patients showed elevated levels in the caudate nucleus and reduced levels in the ACC [110, 111]. However, a more recent study using $3 \mathrm{~T}$ protonmagnetic resonance spectroscopy to quantify neurometabolite concentrations in the ACC, found no difference in concentration of glutamate plus glutamine in OCD patients compared to healthy controls [112].

The possibility of glutamatergic system involvement in OCD pathology has also spurred some interest in the effect of glutamate-modulating agents in the treatment of OCD [13]. Riluzole, which inhibits specific voltage-gated sodium channels, reduces glutamate release, in addition to enhancing glial uptake of extrasynaptic glutamate [113]. Riluzole has shown some positive clinical responses in refractory OCD patients [114]. However, in more controlled studies, results have shown only minimal benefits $[115,116]$.

Another drug target that has been explored for treatment of OC symptoms is the N-methyl-D-aspartate (NMDA) excitatory glutamate receptors. As described above, some studies have shown increased central nervous system glutamate concentrations in OCD patients; therefore, NMDA receptor antagonism has been proposed to dampen excess glutamate signaling. Memantine and ketamine, NMDA receptor blockers, have produced some positive results in small clinical trials [13].

Overall, investigations of glutamate involvement in OCD pathology have yielded interesting results that appear to be promising avenues for future research. How-

Hormones and Neurotransmitters in OCD ever, to date, many of the findings have been far from conclusive; thus, the glutamatergic system is only speculated to be involved in OCD at this point in time [117].

\section{The CSTC Circuit in OCD}

It has been suggested that glutamate hyperactivity creates an imbalance in signaling in the CSTC circuitry, which has been implicated in OCD [118]. In a normally functioning CSTC circuit, glutamatergic signals from the OFC and the ACC excite the striatum. From this point, a balance of 2 pathways is possible: (1) direct pathway: striatal activation sends inhibitory $\gamma$-aminobutyric acid (GABA) signals to the globus pallidus internal (GPi) and the substantia nigra reticulata $(\mathrm{SNr})$, which in turn decrease GABA output from the GPi and SNr to the thalamus, leading to excitatory glutamatergic output from the thalamus to the OFC and ACC; (2) indirect pathway: striatal activation inhibits the globus pallidus external, which decreases its inhibitory signals to the subthalamic nucleus (STN), which is now free to excite the GPi and $\mathrm{SNr}$ which will inhibit the thalamus and subsequent activation of the OFC and ACC [119]. These pathways are illustrated in Figure 2. It has been proposed that a skewing of the balance towards the direct pathway, which may be associated with glutamate hyperactivity, could lead to OC symptom development [118]. This ultimately results in increased stimulation of the OFC, which mediates exaggerated concerns about danger, hygiene, and harm, resulting in persistent attention to the perceived threat, followed by compulsions aimed to address the threat. Alternatively, it is speculated that a dysfunction of the striatum decreases inhibition of GPe, leading to increased inhibition of the STN, effectively decreasing excitation of the $\mathrm{GPi} / \mathrm{SNr}$ similarly increasing excitatory output from the thalamus to the OFC [120]. In terms of the nature of the glutamatergic dysfunction, evidence points to postsynaptic dysfunction in glutamate signaling to explain the changes seen in the CSTC circuitry of OCD patients. Specifically, the glutamate transporter EAAT3/EAAC1, which is located on postsynaptic membranes is thought to be involved [118].

\section{Estradiol and Glutamate}

Estrogens are well known to modulate glutamatergic activity in the central nervous system. Studies in rats have suggested that estrogen demonstrates regionally specific effects on glutamate receptors in the brain. The literature suggests that estrogen exerts its effects on the glutamatergic system by modulating presynaptic glutamate release, and regulation of receptor and protein expression. These

Neuroendocrinology 2017;105:1-16 DOI: $10.1159 / 000453664$ 
Table 4. Effect of gonadal hormones on the glutamatergic system and OCD symptoms

\begin{tabular}{|c|c|c|c|}
\hline Hormone & $\begin{array}{l}\text { Effect on } \\
\text { glutamatergic } \\
\text { system }\end{array}$ & $\begin{array}{l}\text { Overall } \\
\text { effect }\end{array}$ & $\begin{array}{l}\text { Theorized } \\
\text { consequence on } \\
\text { OCD }\end{array}$ \\
\hline \multirow[t]{2}{*}{ Estradiol } & $\begin{array}{l}\uparrow \text { glutamate release } \\
\uparrow \text { NMDA receptor } \\
\uparrow \mathrm{mGluR} 1 \\
\uparrow \text { synapse assembly }\end{array}$ & $\begin{array}{l}\uparrow \text { glutamate } \\
\text { signaling }\end{array}$ & $\begin{array}{l}\text { worsened OCD } \\
\text { symptoms }\end{array}$ \\
\hline & $\begin{array}{l}\text { unclear effect on } \\
\text { AMPA receptor } \\
\text { and EAAT }\end{array}$ & $\begin{array}{l}\text { unknown } \\
\text { effect on } \\
\text { glutamate } \\
\text { signaling }\end{array}$ & $\begin{array}{l}\text { unknown effect } \\
\text { on OCD } \\
\text { symptoms }\end{array}$ \\
\hline Progesterone & $\uparrow$ EAAT3 & $\begin{array}{l}\downarrow \text { glutamate } \\
\text { signaling }\end{array}$ & $\begin{array}{l}\text { improved OCD } \\
\text { symptoms }\end{array}$ \\
\hline
\end{tabular}

effects, as well as the presumed consequences for OCD symptoms are summarized in Table 4.

(1) Evidence for increased presynaptic glutamate release

Evidence demonstrates that estradiol increases glutamate release in the hippocampus. Studies applying estradiol to hippocampal brain slices noted increased excitatory postsynaptic potential slopes $[121,122]$. A study by Schwarz et al. [123] found that estradiol also increases glutamate release in the hypothalamus, activating a signaling cascade that leads to dendritic spine formation, and creation of new synapses.

However, estrogen has also been shown to play a neuroprotective role against glutamate excitotoxicity, suggesting that it may also act to inhibit glutamatergic neurotransmission. Kuo et al. [124] found that administration of tamoxifen, an estrogen receptor (ER) modulator, inhibits $\mathrm{Ca}^{2+}$ entry into the presynaptic neuron, thereby inhibiting protein kinase $\mathrm{C}$, which is needed for presynaptic glutamate exocytosis. Other possible mechanisms include activation of metabotropic glutamate receptors (mGluRs), and modulation of NMDARs in cases of increased intracellular $\mathrm{Ca}^{2+}$ concentrations [125].

(2) Evidence for glutamate receptor modulation

In OVX rats, it has been shown that estradiol treatment increases mRNA and protein expression levels of NMDA [126]. Estradiol has also been shown to increase NMDA receptors in the dentate gyrus of the hippocampus, while in the frontal cortex and caudate putamen, a decrease in NMDA receptors was observed. Conversely, a-amino-3-hydroxy-5-methyl-4-isoxazolepropionic acid (AMPA) receptor density in the frontal cortex, caudate putamen, and nucleus accumbens was observed to decrease with estradiol treatment [127]. However, a later study by Le Saux and Di Paolo [128] found that estradiol increases AMPA binding in the prefrontal cortex, cingulate cortex, and striatum, and that these effects are mediated by ER- $\alpha$. The extracellular ER GPR30 is also suggested to be involved in modulation of AMPA, as a GPR30 agonist was shown to upregulate production of the GluR1 subunit of the AMPA receptor [129].

Estradiol has also been shown to modulate the activity of the mGluRs. In one study, treatment of hippocampal slices of OVX rats with estradiol benzoate resulted in increased $m$ GluR1 protein expression. The downstream effect was an increase in NMDARs, suggesting that estradiol does not directly affect the NMDAR, but rather does so through an mGluR1-dependent mechanism [130].

(3) Evidence for glutamate transporter modulation

Investigations into the effect of estradiol on the EAATs have produced inconsistent results. Some studies found that treatment with estradiol enhanced EAAT activity in astrocytes $[131,132]$. In contrast, 1 study reported a decrease in glutamate uptake, with another study still reporting no change in EAAT1 and EAAT2 levels in response to estradiol treatment $[133,134]$.

(4) Evidence for upregulation of synaptic proteins

Several studies in the literature have implicated estradiol in the formation of new glutamatergic synapses. Cultured hippocampal neurons exposed to acute estradiol treatment demonstrated an increase in vesicular glutamate transporter and NMDA subunits on the dendrites of the cells, suggesting an increase in synaptic density [135]. Subsequent inhibition of this phenomenon with ER antagonists and enhancement with ER agonists further confirmed the role of estradiol and its receptors in synapse formation [135]. It was found that estradiol upregulates a number of synaptic proteins in the hippocampus including GluR1 and Kalirin-7 [136, 137].

Based on our current understanding, excessive glutamate signaling in the CSTC loop may be involved in OCD. However, it is difficult to determine the role of estradiol in this signaling pathway as results from investigations have been inconsistent, suggesting estradiol both up- and downregulates different components of the glutamatergic neurotransmitter system.

\section{Progesterone and Glutamate}

The neuromodulatory effects of progesterone on glutamatergic signaling have been less well characterized. One study found that progesterone had no effect on spontaneous glutamate release, but appeared to inhibit dopa- 
mine-evoked glutamate release [138]. The investigators speculate that progesterone blocks the sigma-1 receptors, which act synergistically with the dopamine D1 receptor to inhibit downstream signaling eventually inhibiting glutamate release.

Bethea and Reddy studied expression of a variety of glutamatergic synaptic proteins in the midbrain of OVX macaques after estradiol or estradiol and progesterone combination therapy. While estradiol and estradiol and progesterone treatments induced significant upregulation of several glutamatergic synaptic proteins, the effects of estradiol and progesterone combination treatment were not significantly different from those of estradiol alone. Progesterone is thought to induce only minor upregulation of the aforementioned proteins [139]. Another study to examine the effect of progesterone on NMDA also found no enhanced receptor binding effects [140]. In a study by Cyr et al. [127], progesterone treatment in OVX rats was found to decrease NMDA but not AMPA binding density in the frontal cortex, and had no effect in the hippocampus, dentate gyrus, striatum, and nucleus accumbens. Another study showed significantly enhanced EAAT3 activity after progesterone treatment performed in frog oocytes [141]. Mitrovic et al. [142] studied this association in cell cultures from rat brain and similarly found that EAAT affinity for glutamate was highest during proestrous and estrous periods, which are characterized by peak levels of both estradiol and progesterone. No acute effects of progesterone were observed in EAAT1 or EAAT2, leading the researchers to suggest that regulation is done through a genomic mechanism which usually takes a longer time to induce observable changes [142].

\section{Oxytocin in OCD}

There have been a few studies attempting to associate oxytocin directly with OC symptoms; however, results have been inconsistent. It has been previously reported that there are elevated oxytocin plasma levels in OCD patients $[143,144]$. Since OC behaviors appear to be extreme versions of the behaviors induced by oxytocin, it is thought that the hormone may play a neuroregulatory role in OCD pathology [145]. Humble et al. [146] found a positive correlation between oxytocin levels and YBOCS scores amongst SRI-responsive patients (2013). Furthermore, treatment with the SRIs clomipramine and paroxetine modulated oxytocin levels, suggesting another antiobsessive function of SRIs. Other studies have reported no association between oxytocin and OCD [147, 148]. These results should be interpreted with caution as only small samples of patients were used.

Hormones and Neurotransmitters in OCD
Alternatively, oxytocin may be involved in OCD pathology through its neuromodulatory effects on other neurotransmitter systems. A study by Yoshida et al. [149] has suggested that oxytocin increases serotonin release. Evidence has led to the speculation that this is a result of direct activation of the oxytocin receptor found in serotonergic neurons, specifically in the raphe nuclei [149].

\section{Hormonal Modulation of OC Symptoms}

The neuromodulatory effects of estradiol have been investigated much more extensively compared to those of other reproductive hormones. Increased estradiol levels have been shown to increase serotonergic neurotransmission, which has been associated with an improvement in symptoms. Results from dopamine and glutamate signaling have been much more variable, as such making it difficult to draw an overall conclusion.

These results are also consistent with the clinical data. Vulink et al. [35] reported an exacerbation of OC symptoms in healthy controls beginning 4 days before the start of menstruation. Estradiol is known to decrease around the 22nd day of a 28-day cycle; thus, an exacerbation of OC symptoms after this time would be expected. During pregnancy, estradiol levels gradually increase over the course of the 9 -month period. Interestingly, a study by Kaya et al. [150] found that the onset of pregnancy-related OCD was much more common in the first and second trimesters, which are characterized by comparatively lower estradiol levels than the third trimester. The early postpartum period is known to involve as much as a 1,000 -fold drop in estradiol levels compared to the pregnant state [37]. Other studies have reported up to 50 and $25 \%$ of subjects experiencing worsening and onset in the postpartum period, respectively [151]. Women may be more prone to developing or experiencing a worsening of OC symptoms during this time of low neuroprotective estradiol levels.

Progesterone has been studied less thoroughly; however, it also generally appears to increase serotonin neurotransmission. Similarly to estradiol, progesterone levels also drop around the 22nd day of the menstrual cycle; thus, the results of Vulink et al. [35] may also be attributed to decreased progesterone levels. Additionally, progesterone levels increase during pregnancy, and plummet after delivery, and could therefore also be an impetus to pregnancy- or postpartum-related OCD.

Evidence for involvement of oxytocin in modulation of OC symptoms is currently inconclusive, and further

Neuroendocrinology 2017;105:1-16 DOI: $10.1159 / 000453664$ 
investigation is necessary to confirm its role. With some studies reporting high oxytocin plasma levels in individuals with OCD, it is possible that the increase in oxytocin during delivery and breastfeeding in the postpartum period may also contribute to development or worsening of OC symptoms.

Although not much is known about its role in OCD, the reproductive hormone testosterone has also been shown to increase during pregnancy $[152,153]$. Testosterone, which is known to modulate neurotransmission, may be another hormone worth studying in pregnancyrelated OCD. Maternal plasma testosterone levels, which differ depending on the sex of the offspring may have a differential impact on OCD severity [153].

As with most other psychiatric disorders, OCD appears to have a number of alternative factors that contribute to the illness. While the hormonal changes during female reproductive events are a plausible mechanism for changes in OCD course, they may only serve as a precipitating factor in individuals already predisposed to the condition. Furthermore, although this review examined each neurotransmitter separately, it is important to keep in mind that the brain is an intricate system of signaling pathways that do not function independently and may all become dysregulated in the OCD pathological state (Fig. 1).

\section{Conclusion}

Current lines of evidence suggest a role for gonadal hormones in OCD pathology. Estrogen and progesterone have been shown to modulate serotonergic, dopaminergic, and glutamatergic neurotransmission, and these neurotransmitter systems have been shown to be dysregulated in OC patients. From this evidence, it can be inferred that hormones play an important role in influencing the course of OCD. Further investigation into this relationship is warranted. Future studies should prospectively evaluate OC symptom severity along the course of female reproductive events, with concurrent measurements of hormone levels.

\section{References}

1 American Psychiatric Association: Diagnostic and Statistical Manual of Mental Disorders $\left(\mathrm{DSM}-5^{\circledR}\right)$. Arlington, American Psychiatric Publishing, 2013.

2 Uguz F, Akman C, Kaya N, Cilli AS: Postpartum-onset obsessive-compulsive disorder: incidence, clinical features, and related factors. J Clin Psychiatry 2007;68:132-138.

3 Mattina GF, Steiner M: The need for inclusion of sex and age of onset variables in genetic association studies of obsessive-compulsive disorder: overview. Prog Neuropsychopharmacol Biol Psychiatry 2016;67:107-116.

4 Forray A, Focseneanu M, Pittman B, McDougle CJ, Epperson CN: Onset and exacerbation of obsessive-compulsive disorder in pregnancy and the postpartum period. J Clin Psychiatry 2010;71:1061-1068.

5 Guglielmi V, Vulink NCC, Denys D, Wang Y, Samuels JF, Nestadt G: Obsessive-compulsive disorder and female reproductive cycle events: results from the OCD and reproduction collaborative study. Depress Anxiety 2014;31:979-987.

6 Uguz F, Kaya V, Gezginc K, Kayhan F, Cicek E: Clinical correlates of worsening in obsessive-compulsive symptoms during pregnancy. Gen Hosp Psychiatry 2011;33:197-199.

7 Russell EJ, Fawcett JM, Mazmanian D: Risk of obsessive-compulsive disorder in pregnant and postpartum women: a meta-analysis. J Clin Psychiatry 2013;74:377-385.
8 Avgoustinaki PD, Mitsopoulou E, Chlouverakis G, Triantafillou T, Venihaki M, Koukouli $\mathrm{S}$, et al: Sex steroids and personality traits in the middle luteal phase of healthy normally menstruating young professional women. Hormones (Athens) 2012;11:333-343.

9 Fernández-Guasti A, Agrati D, Reyes R, Ferreira A: Ovarian steroids counteract serotonergic drugs actions in an animal model of obsessive-compulsive disorder. Psychoneuroendocrinology 2006;31:924-934.

10 Yadin E, Friedman E, Bridger WH: Spontaneous alternation behavior: an animal model for obsessive-compulsive disorder? Pharmacol Biochem Behav 1991;40:311-315.

11 Flaisher-Grinberg S, Albelda N, Gitter L, Weltman K, Arad M, Joel D: Ovarian hormones modulate "compulsive" lever-pressing in female rats. Horm Behav 2009;55:356-365.

12 Stein DJ: Obsessive-compulsive disorder. Lancet 2002;360:397-405.

13 Pittenger C, Bloch MH, Williams K: Glutamate abnormalities in obsessive compulsive disorder: neurobiology, pathophysiology, and treatment. Pharmacol Ther 2011;132:314332.

14 Broocks A, Pigott TA, Hill JL, Canter S, Grady TA, L'heureux F, et al: Acute intravenous administration of ondansetron and m-CPP, alone and in combination, in patients with obsessive-compulsive disorder OCD : behavioral and biological results. Psychiatry Res 1998;79:11-20.
15 Fineberg NA, Reghunandanan S, Brown A, Pampaloni I: Pharmacotherapy of obsessivecompulsive disorder: evidence-based treatment and beyond. Aust N Z J Psychiatry 2013; 47:121-141.

16 Insel TR, Mueller EA, Alterman I, Linnoila M, Murphy DL: Obsessive-compulsive disorder and serotonin: is there a connection? Biol Psychiatry 1985;20:1174-1188.

17 Stengler-Wenzke K, Müller U, Angermeyer MC, Sabri O, Hesse S: Reduced serotonin transporter-availability in obsessive-compulsive disorder (OCD). Eur Arch Psychiatry Clin Neurosci 2004;254:252-255.

18 Hesse S, Müller U, Lincke T, Barthel H, Villmann T, Angermeyer MC, et al: Serotonin and dopamine transporter imaging in patients with obsessive-compulsive disorder. Psychiatry Res Neuroimaging 2005;140:63-72.

19 Zitterl W, Aigner M, Stompe T, Zitterl-Eglseer K, Gutierrez-Lobos K, Schmidl-Mohl B, et al: [123I]-beta-CIT SPECT imaging shows reduced thalamus-hypothalamus serotonin transporter availability in 24 drug-free obsessive-compulsive checkers. Neuropsychopharmacology 2007;32:1661-1668.

20 Zitterl W, Aigner M, Stompe T, Zitterl-Eglseer $\mathrm{K}$, Gutierrez-Lobos $\mathrm{K}$, Wenzel T, et al: Changes in thalamus-hypothalamus serotonin transporter availability during clomipramine administration in patients with obsessive-compulsive disorder. Neuropsychopharmacology 2008;33:3126-3134. 
21 Pogarell O, Hamann C, Pöpperl G, Juckel G, Choukèr $M$, Zaudig $M$, et al: Elevated brain serotonin transporter availability in patients with obsessive-compulsive disorder. Biol Psychiatry 2003;54:1406-1413.

22 Simpson HB, Lombardo I, Slifstein M, Huang HY, Hwang D-R, Abi-Dargham A, et al: Serotonin transporters in obsessive-compulsive disorder: a positron emission tomography study with [11C]McN 5652. Biol Psychiatry 2003;54:1414-1421.

23 Bethea CL, Reddy AP: Effect of ovarian steroids on gene expression related to synapse assembly in serotonin neurons of macaques. J Neurosci Res 2012;90:1324-1334.

24 Lokuge S, Frey BN, Foster JA, Soares CN, Steiner M: Depression in women: windows of vulnerability and new insights into the link between estrogen and serotonin. J Clin Psychiatry 2011;72:e1563-e1569.

25 Kunimura Y, Iwata K, Iijima N, Kobayashi M, Ozawa $\mathrm{H}$ : Effect of sex steroid hormones on the number of serotonergic neurons in rat dorsal raphe nucleus. Neurosci Lett 2015;594: 127-132.

26 Pecins-Thompson M, Brown NA, Kohama SG, Bethea CL: Ovarian steroid regulation of tryptophan hydroxylase mRNA expression in rhesus macaques. J Neurosci 1996;16:70217029.

27 Aggarwal M, Puri V, Puri S: Effects of estrogen on the serotonergic system and calcitonin gene-related peptide in trigeminal ganglia of rats. Ann Neurosci 2012;19:151-157.

28 Sanchez RL, Reddy AP, Centeno ML, Henderson JA, Bethea CL: A second tryptophan hydroxylase isoform, TPH-2 mRNA, is increased by ovarian steroids in the raphe region of macaques. Mol Brain Res 2005;135: 194-203.

29 Bethea CL, Mirkes SJ, Shively CA, Adams MR: Steroid regulation of tryptophan hydroxylase protein in the dorsal raphe of macaques. Biol Psychiatry 2000;47:562-576.

30 Smith LJ, Henderson JA, Abell CW, Bethea CL: Effects of ovarian steroids and raloxifene on proteins that synthesize, transport, and degrade serotonin in the raphe region of macaques. Neuropsychopharmacology 2004;29: 2035-2045

31 Hildebrandt T, Alfano L, Tricamo M, Pfaff DW: Conceptualizing the role of estrogens and serotonin in the development and maintenance of bulimia nervosa. Clin Psychol Rev 2010;30:655-668.

32 Luine VN, McEwen BS: Effect of oestradiol on turnover of type A monoamine oxidase in brain. J Neurochem 1977;28:1221-1227.

33 Ortega-Corona BG, Valencia-Sánchez A, Kubli-Garfias C, Anton-Tay F, Salazar LA, Villarreal JE, et al: Hypothalamic monoamine oxidase activity in ovariectomized rats after sexual behavior restoration. Arch Med Res 1994;25:337-340.
34 Holschneider DP, Kumazawa T, Chen K, Shih JC: Tissue-specific effects of estrogen on monoamine oxidase A and B in the rat. Life Sci 1998;63:155-160.

35 Vulink NCC, Denys D, Bus L, Westenberg HGM: Female hormones affect symptom severity in obsessive-compulsive disorder. Int Clin Psychopharmacol 2006;21:171-175.

36 Skovlund CW, Mørch LS, Kessing LV, Lidegaard $\varnothing$ : Association of hormonal contraception with depression. JAMA Psychiatry 2016; 382:1575-1586.

37 Sacher J, Wilson AA, Houle S, Rusjan P, Hassan S, Bloomfield PM, et al: Elevated brain monoamine oxidase A binding in the early postpartum period. Arch Gen Psychiatry 2010;67:468-474.

38 Rekkas PV, Wilson AA, Lee VWH, Yogalingam P, Sacher J, Rusjan P, et al: Greater monoamine oxidase a binding in perimenopausal age as measured with carbon 11-labeled harmine positron emission tomography. JAMA Psychiatry 2014;71:873-879.

39 Sumner BE, Grant KE, Rosie R, HegeleHartung C, Fritzemeier K-H, Fink G: Effects of tamoxifen on serotonin transporter and 5-hydroxytryptamine $(2 \mathrm{~A})$ receptor binding sites and mRNA levels in the brain of ovariectomized rats with or without acute estradiol replacement. Mol Brain Res 1999;73:119128.

40 McQueen JK, Wilson H, Fink G: Estradiol$17 \beta$ increase serotonin transporter (SERT) mRNA levels and the density of SERT-binding sites in female rat brain. Mol Brain Res 1997;45:13-23.

41 Pecins-Thompson M, Brown NA, Bethea CL: Regulation of serotonin re-uptake transporter mRNA expression by ovarian steroids in rhesus macaques. Brain Res Mol Brain Res 1998; 53:120-129.

42 Charoenphandhu J, Teerapornpuntakit J, Nuntapornsak A, Krishnamra N, Charoenphandhu N: Anxiety-like behaviors and expression of SERT and TPH in the dorsal raphé of estrogen- and fluoxetine-treated ovariectomized rats. Pharmacol Biochem Behav 2011; 98:503-510.

43 Chavez C, Hollaus M, Scarr E, Pavey G, Gogos $A$, van den Buuse M: The effect of estrogen on dopamine and serotonin receptor and transporter levels in the brain: an autoradiography study. Brain Res 2010;1321:51-59.

44 Frokjaer VG, Pinborg A, Holst KK, Overgaard A, Henningsson S, Heede M, et al: Role of serotonin transporter changes in depressive responses to sex-steroid hormone manipulation: a positron emission tomography study. Biol Psychiatry 2015;78:534-543.

45 Kranz GS, Wadsak W, Kaufmann U, Savli M, Baldinger P, Gryglewski G, et al: High-dose testosterone treatment increases serotonin transporter binding in transgender people. Biol Psychiatry 2015;78:525-533.
46 Jovanovic $\mathrm{H}$, Kocoska-Maras L, Rådestad AF, Halldin C, Borg J, Hirschberg AL, et al: Effects of estrogen and testosterone treatment on serotonin transporter binding in the brain of surgically postmenopausal women - a PET study. Neuroimage 2015;106:47-54.

47 Akimova E, Lanzenberger R, Kasper S: The serotonin-1A receptor in anxiety disorders. Biol Psychiatry 2009;66:627-635.

48 Österlund MK, Hurd YL: Acute 17 $\beta$-estradiol treatment down-regulates serotonin $5 \mathrm{HT} 1 \mathrm{~A}$ receptor mRNA expression in the limbic system of female rats. Mol Brain Res 1998;55: 169-172.

49 Sánchez MG, Estrada-Camarena E, Bélanger N, Morissette M, Di Paolo T: Estradiol modulation of cortical, striatal and raphe nucleus 5-HT1A and 5-HT2A receptors of female hemiparkinsonian monkeys after long-term ovariectomy. Neuropharmacology 2011;60: 642-652.

50 Creech RD, Li Q, Carrasco GA, Van de Kar LD, Muma NA: Estradiol induces partial desensitization of serotonin $1 \mathrm{~A}$ receptor signaling in the paraventricular nucleus of the hypothalamus and alters expression and interaction of RGSZ1 and Gaz. Neuropharmacology 2012;62:2040-2049.

51 Hiroi R, Neumaier JF: Estrogen decreases 5-HT1B autoreceptor mRNA in selective subregion of rat dorsal raphe nucleus: inverse association between gene expression and anxiety behavior in the open field. Neuroscience 2009;158:456-464.

52 Kranz GS, Rami-Mark C, Kaufmann U, Baldinger P, Hahn A, Höflich A, et al: Effects of hormone replacement therapy on cerebral serotonin-1A receptor binding in postmenopausal women examined with [carbonyl-11C] WAY-100635. Psychoneuroendocrinology 2014;45:1-10.

53 Zhang G, Stackman RW: The role of serotonin 5-HT2A receptors in memory and cognition. Front Pharmacol 2015;6:225.

54 Sumner BE, Fink G: Estrogen increases the density of 5-hydroxytryptamine(2A) receptors in cerebral cortex and nucleus accumbens in the female rat. J Steroid Biochem Mol Biol 1995;54:15-20.

55 Moses EL, Drevets WC, Smith G, Mathis CA, Kalro BN, Butters MA, et al: Effects of estradiol and progesterone administration on human serotonin $2 \mathrm{~A}$ receptor binding: a PET study. Biol Psychiatry 2000;48:854-860.

56 Kugaya A, Epperson CN, Zoghbi S, van Dyck $\mathrm{CH}$, Hou Y, Fujita M, et al: Increase in prefrontal cortex serotonin $2 \mathrm{~A}$ receptors following estrogen treatment in postmenopausal women. Am J Psychiatry 2003;160:15221524.

57 Compton J, Travis MJ, Norbury R, Erlandsson K, van Amelsvoort T, Daly E, et al: Longterm estrogen therapy and 5-HT2A receptor binding in postmenopausal women; a single photon emission tomography (SPET) study. Horm Behav 2008;53:61-68.
Hormones and Neurotransmitters in OCD
Neuroendocrinology 2017;105:1-16 DOI: $10.1159 / 000453664$ 
58 Lu NZ, Shlaes TA, Gundlah C, Dziennis SE, Lyle RE, Bethea CL: Ovarian steroid action on tryptophan hydroxylase protein and serotonin compared to localization of ovarian steroid receptors in midbrain of guinea pigs. Endocrine 1999;11:257-267.

59 Gereau RW, Kedzie KA, Renner KJ: Effect of progesterone on serotonin turnover in rats primed with estrogen implants into the ventromedial hypothalamus. Brain Res Bull 1993; 32:293-300.

60 Bethea CL, Gundlah C, Mirkes SJ: Ovarian steroid action in the serotonin neural system of macaques. Novartis Found Symp 2000;230: 112-130; discussion 130-133.

61 Bethea CL, Lu NZ, Gundlah C, Streicher JM: Diverse actions of ovarian steroids in the serotonin neural system. Front Neuroendocrinol 2002;23:41-100.

62 Gundlah C, Lu NZ, Bethea CL: Ovarian steroid regulation of monoamine oxidase- $A$ and -B mRNAs in the macaque dorsal raphe and hypothalamic nuclei. Psychopharmacology (Berl) 2002;160:271-282.

63 Stein P, Baldinger P, Kaufmann U, Christina R-M, Hahn A, Höflich A, et al: Relation of progesterone and DHEAS serum levels to 5-HT1A receptor binding potential in preand postmenopausal women. Psychoneuroendocrinology 2014;46:52-63.

64 Birzniece V, Johansson I-M, Wang M-D, Bäckström T, Olsson T: Ovarian hormone effects on 5-hydroxytryptamine2A and 5-hydroxytryptamine $2 \mathrm{C}$ receptor mRNA expression in the ventral hippocampus and frontal cortex of female rats. Neurosci Lett 2002;319: 157-161.

65 Koo M-S, Kim E-J, Roh D, Kim C-H: Role of dopamine in the pathophysiology and treatment of obsessive-compulsive disorder. Expert Rev Neurother 2010;10:275-290.

66 Stein DJ: Neurobiology of the obsessive-compulsive spectrum disorders. Biol Psychiatry 2000;47:296-304.

67 Vulink NCC, Denys D, Westenberg HGM: Bupropion for patients with obsessive-compulsive disorder: an open-label, fixed-dose study. J Clin Psychiatry 2005;66:228-230.

68 Szechtman H, Sulis W, Eilam D: Quinpirole induces compulsive checking behavior in rats: a potential animal model of obsessive-compulsive disorder (OCD). Behav Neurosci 1998;112:1475-1485.

69 Eagle DM, Noschang C, d'Angelo L-SC, Noble CA, Day JO, Dongelmans ML, et al: The dopamine D2/D3 receptor agonist quinpirole increases checking-like behaviour in an operant observing response task with uncertain reinforcement: a novel possible model of OCD. Behav Brain Res 2014;264:207-229.

70 Moresco RM, Pietra L, Henin M, Panzacchi A, Locatelli M, Bonaldi L, et al: Fluvoxamine treatment and D2 receptors: a pet study on OCD drug-naïve patients. Neuropsychopharmacology 2007;32:197-205.
71 Kapur S, Remington G: Serotonin-dopamine interaction and its relevance to schizophrenia. Am J Psychiatry 1996;153:466-476.

72 Denys D, Zohar J, Westenberg HGM: The role of dopamine in obsessive-compulsive disorder: preclinical and clinical evidence. J Clin Psychiatry 2004;6565:11-17.

73 Metin O, Yazici K, Tot S, Yazici AE: Amisulpiride augmentation in treatment resistant obsessive-compulsive disorder: an open trial. Hum Psychopharmacol 2003;18:463-467.

74 Olver JS, O'Keefe G, Jones GR, Burrows GD, Tochon-Danguy HJ, Ackermann U, et al: Dopamine D1 receptor binding in the striatum of patients with obsessive-compulsive disorder. J Affect Disord 2009;114:321-326.

75 Olver JS, O’Keefe G, Jones GR, Burrows GD, Tochon-Danguy HJ, Ackermann U, et al: Dopamine D1 receptor binding in the anterior cingulate cortex of patients with obsessivecompulsive disorder. Psychiatry Res 2010; 183:85-88.

76 Pitman RK: A cybernetic model of obsessivecompulsive psychopathology. Compr Psychiatry 1987;28:334-343.

77 Denys D, van der Wee N, Janssen J, De Geus F, Westenberg HG: Low level of dopaminergic $\mathrm{D} 2$ receptor binding in obsessive-compulsive disorder. Biol Psychiatry 2004;55:10411045.

78 Perani D, Garibotto V, Gorini A, Moresco RM, Henin M, Panzacchi A, et al: In vivo PET study of 5HT2A serotonin and D2 dopamine dysfunction in drug-naive obsessive-compulsive disorder. Neuroimage 2008;42:306-314.

79 van der Wee NJ, Stevens H, Hardeman JA, Mandl RC, Denys DA, van Megen HJ, et al: Enhanced dopamine transporter density in psychotropic-naive patients with obsessivecompulsive disorder shown by [123I]\{beta $\}$ CIT SPECT. Am J Psychiatry 2004;161:22012206.

80 Pogarell O, Poepperl G, Mulert C, Hamann C, Sadowsky N, Riedel M, et al: SERT and DAT availabilities under citalopram treatment in obsessive-compulsive disorder (OCD). Eur Neuropsychopharmacol 2005;15:521-524.

81 Di Paolo T: Modulation of brain dopamine transmission by sex steroids. Rev Neurosci 1994;5:27-41.

82 McDermott JL, Liu B, Dluzent DE: Sex differences and effects of estrogen on dopamine and DOPAC release from the striatum of male and female CD-1 mice. Exp Neurol 1994;125:306-311.

83 Zsarnovszky A, Scalise TJ, Horvath TL, Naftolin F: Estrogen effects on tyrosine hydroxylase-immunoreactive cells in the ventral mesencephalon of the female rat: further evidence for the two cell hypothesis of dopamine function. Brain Res 2000;868:363-366.

84 Kritzer M, Adler A, Bethea C: Ovarian hormone influences on the density of immunoreactivity for tyrosine hydroxylase and serotonin in the primate corpus striatum. Neuroscience 2003;122:757-772.
85 Becker JB: Gender differences in dopaminergic function in striatum and nucleus accumbens. Pharmacol Biochem Behav 1999;64: 803-812.

86 Becker JB: Direct effect of 17 beta-estradiol on striatum: sex differences in dopamine release. Synapse 1990;5:157-164.

87 Thompson TL, Moss RL: Estrogen regulation of dopamine release in the nucleus accumbens: genomic- and nongenomic-mediated effects. J Neurochem 1994;62:1750-1756.

88 Bossé R, Rivest R, Di Paolo T: Ovariectomy and estradiol treatment affect the dopamine transporter and its gene expression in the rat brain. Brain Res Mol Brain Res 1997;46:343346.

89 Sánchez MG, Morissette M, Di Paolo T: Effect of a chronic treatment with $17 \beta$-estradiol on striatal dopamine neurotransmission and the Akt/GSK3 signaling pathway in the brain of ovariectomized monkeys. Psychoneuroendocrinology 2012;37:280-291.

90 Gardiner SA, Morrison MF, Mozley PD, Mozley LH, Brensinger C, Bilker W, et al: Pilot study on the effect of estrogen replacement therapy on brain dopamine transporter availability in healthy, postmenopausal women. Am J Geriatr Psychiatry 2004;12:621-630.

91 Zhou W, Cunningham KA, Thomas ML: Estrogen regulation of gene expression in the brain: a possible mechanism altering the response to psychostimulants in female rats. Mol Brain Res 2002;100:75-83.

92 Attali G, Weizman A, Gil-Ad I, Rehavi M: Opposite modulatory effects of ovarian hormones on rat brain dopamine and serotonin transporters. Brain Res 1997;756:153-159.

93 Lévesque D, Di Paolo T: Effect of the rat estrous cycle at ovariectomy on striatal D-1 dopamine receptors. Brain Res Bull 1990;24: 281-284.

94 Bossé R, DiPaolo T: The modulation of brain dopamine and GABAA receptors by estradiol: a clue for CNS changes occurring at menopause. Cell Mol Neurobiol 1996;16:199-212.

95 Lévesque D, Di Paolo T: Chronic estradiol treatment increases ovariectomized rat striatal D-1 dopamine receptors. Life Sci 1989;45: 1813-1820.

96 Lévesque D, Di Paolo T: Dopamine receptor reappearance after irreversible receptor blockade: effect of chronic estradiol treatment of ovariectomized rats. Mol Pharmacol 1991; 39:659-665.

97 Lévesque D, Gagnon S, Di Paolo T: Striatal D1 dopamine receptor density fluctuates during the rat estrous cycle. Neurosci Lett 1989;98: 345-350.

98 Lévesque D, Di Paolo T: Rapid conversion of high into low striatal D2-dopamine receptor agonist binding states after an acute physiological dose of 17 beta-estradiol. Neurosci Lett 1988;88:113-118. 
99 Landry M, Lévesque D, Di Paolo T: Estrogenic properties of raloxifene, but not tamoxifen, on $\mathrm{D} 2$ and $\mathrm{D} 3$ dopamine receptors in the rat forebrain. Neuroendocrinology 2002; 76:214-222.

100 Nordström AL, Olsson H, Halldin C: A PET study of D2 dopamine receptor density at different phases of the menstrual cycle. Psychiatry Res 1998;83:1-6.

101 Di Paolo T, Lévesque D, Daigle M: A physiological dose of progesterone affects rat striatum biogenic amine metabolism. Eur J Pharmacol 1986;125:11-16.

102 Petitclerc M, Bédard PJ, Di Paolo T: Progesterone releases dopamine in male and female rat striatum: a behavioral and microdialysis study. Prog Neuropsychopharmacol Biol Psychiatry 1995;19:491-497.

103 Becker JB, Rudick CN: Rapid effects of estrogen or progesterone on the amphetamineinduced increase in striatal dopamine are enhanced by estrogen priming: a microdialysis study. Pharmacol Biochem Behav 1999;64:53-57.

104 Morissette M, Di Paolo T: Effect of chronic estradiol and progesterone treatments of ovariectomized rats on brain dopamine uptake sites. J Neurochem 1993;60:1876-1883.

105 Morissette M, Biron D, Di Paolo T: Effect of estradiol and progesterone on rat striatal dopamine uptake sites. Brain Res Bull 1990;25: 419-422.

106 Fernández-Ruiz JJ, Amor JC, Ramos JA: Time-dependent effects of estradiol and progesterone on the number of striatal dopaminergic D2-receptors. Brain Res 1989; 476:388-395.

107 Lévesque D, Di Paolo T: Modulation by estradiol and progesterone of the GTP effect on striatal D-2 dopamine receptors. Biochem Pharmacol 1993;45:723-733.

108 Chakrabarty K, Bhattacharyya S, Christopher R, Khanna S: Glutamatergic dysfunction in OCD. Neuropsychopharmacology 2005;30:1735-1740.

109 Bhattacharyya S, Khanna S, Chakrabarty K, Mahadevan A, Christopher R, Shankar SK: Anti-brain autoantibodies and altered excitatory neurotransmitters in obsessive-compulsive disorder. Neuropsychopharmacology 2009;34:2489-2496.

110 Rosenberg DR, MacMaster FP, Keshavan MS, Fitzgerald KD, Stewart CM, Moore GJ: Decrease in caudate glutamatergic concentrations in pediatric obsessive-compulsive disorder patients taking paroxetine. J Am Acad Child Adolesc Psychiatry 2000;39: 1096-1103.

111 Rosenberg DR, Mirza Y, Russell A, Tang J, Smith JM, Banerjee SP, et al: Reduced anterior cingulate glutamatergic concentrations in childhood OCD and major depression versus healthy controls. J Am Acad Child Adolesc Psychiatry 2004;43:1146-1153.
112 Ortiz AE, Ortiz AG, Falcon C, Morer A, Plana MT, Bargalló N, et al: 1H-MRS of the anterior cingulate cortex in childhood and adolescent obsessive-compulsive disorder: a case-control study. Eur Neuropsychopharmacol 2015;25:60-68.

113 Pittenger C, Coric V, Banasr M, Bloch M, Krystal JH, Sanacora G: Riluzole in the treatment of mood and anxiety disorders. CNS Drugs 2008;22:761-786.

114 Coric V, Milanovic S, Wasylink S, Patel P, Malison R, Krystal JH: Beneficial effects of the antiglutamatergic agent riluzole in a patient diagnosed with obsessive-compulsive disorder and major depressive disorder. Psychopharmacology (Berl) 2003;167:219-220.

115 Pittenger C, Bloch MH, Wasylink S, Billingslea E, Simpson R, Jakubovski E, et al: Riluzole augmentation in treatment-refractory obsessive-compulsive disorder: a pilot randomized placebo-controlled trial. J Clin Psychiatry 2015;76:1075-1084.

116 Grant PJ, Joseph LA, Farmer CA, Luckenbaugh DA, Lougee LC, Zarate CA, et al: 12week, placebo-controlled trial of add-on riluzole in the treatment of childhood-onset obsessive-compulsive disorder. Neuropsychopharmacology 2014;39:1453-1459.

117 Pittenger C: Glutamate modulators in the treatment of obsessive-compulsive disorder. Psychiatr Ann 2015;45:308-315.

118 Wu K, Hanna GL, Rosenberg DR, Arnold PD: The role of glutamate signaling in the pathogenesis and treatment of obsessivecompulsive disorder. Pharmacol Biochem Behav 2012;100:726-735.

119 Pauls DL, Abramovitch A, Rauch SL, Geller DA: Obsessive-compulsive disorder: an integrative genetic and neurobiological perspective. Nat Rev Neurosci 2014;15:410424.

120 Kalra SK, Swedo SE: Children with obsessive-compulsive disorder: are they just "little adults?" J Clin Invest 2009;119:737-746.

121 Teyler TJ, Vardaris RM, Lewis D, Rawitch AB: Gonadal steroids: effects on excitability of hippocampal pyramidal cells. Science 1980;209:1017-1018.

122 Sharrow KM, Kumar A, Foster TC: Calcineurin as a potential contributor in estradiol regulation of hippocampal synaptic function. Neuroscience 2002;113:89-97.

123 Schwarz JM, Liang S-L, Thompson SM, McCarthy MM: Estradiol induces hypothalamic dendritic spines by enhancing glutamate release: a mechanism for organizational sex differences. Neuron 2008;58:584-598.

124 Kuo J, Hariri OR, Bondar G, Ogi J, Micevych $P$ : Membrane estrogen receptor-alpha interacts with metabotropic glutamate receptor type 1a to mobilize intracellular calcium in hypothalamic astrocytes. Endocrinology 2009;150:1369-1376.

125 Lan Y-L, Zhao J, Li S: Estrogen receptors' neuroprotective effect against glutamate-induced neurotoxicity. Neurol Sci 2014;35: 1657-1662.
126 Gazzaley AH, Weiland NG, McEwen BS, Morrison JH: Differential regulation of NMDAR1 mRNA and protein by estradiol in the rat hippocampus. J Neurosci 1996;16:68306838.

127 Cyr M, Ghribi O, Di Paolo T: Regional and selective effects of oestradiol and progesterone on NMDA and AMPA receptors in the rat brain. J Neuroendocrinol 2000;12:445452.

128 Le Saux M, Di Paolo T: Influence of oestrogenic compounds on monoamine transporters in rat striatum. J Neuroendocrinol 2006; 18:25-32.

129 Tian Z, Wang Y, Zhang N, Guo Y, Feng B, Liu S, et al: Estrogen receptor GPR30 exerts anxiolytic effects by maintaining the balance between GABAergic and glutamatergic transmission in the basolateral amygdala of ovariectomized mice after stress. Psychoneuroendocrinology 2013;38:2218-2233

130 Nebieridze N, Zhang X, Chachua T, Velíšek L, Stanton PK, Velíšková J: $\beta$-Estradiol unmasks metabotropic receptor-mediated metaplasticity of NMDA receptor transmission in the female rat dentate gyrus. Psychoneuroendocrinology 2012;37:1845-1854.

131 Keller JN, Germeyer A, Begley JG, Mattson MP: 17Beta-estradiol attenuates oxidative impairment of synaptic $\mathrm{Na}+/ \mathrm{K}+$-ATPase activity, glucose transport, and glutamate transport induced by amyloid beta-peptide and iron. J Neurosci Res 1997;50:522-530.

132 Liang Z, Valla J, Sefidvash-Hockley S, Rogers J, Li R: Effects of estrogen treatment on glutamate uptake in cultured human astrocytes derived from cortex of Alzheimer's disease patients. J Neurochem 2002;80:807814.

133 Sato K, Matsuki N, Ohno Y, Nakazawa K: Estrogens inhibit l-glutamate uptake activity of astrocytes via membrane estrogen receptor alpha. J Neurochem 2003;86:1498-1505.

134 Cimarosti H, O'Shea RD, Jones NM, Horn AP, Simão F, Zamin LL, et al: The effects of estradiol on estrogen receptor and glutamate transporter expression in organotypic hippocampal cultures exposed to oxygenglucose deprivation. Neurochem Res 2006; 31:483-490.

135 Jelks KB, Wylie R, Floyd CL, McAllister AK, Wise P: Estradiol targets synaptic proteins to induce glutamatergic synapse formation in cultured hippocampal neurons: critical role of estrogen receptor-alpha. J Neurosci 2007; 27:6903-6913.

136 Waters EM, Mitterling K, Spencer JL, Mazid S, McEwen BS, Milner TA: Estrogen receptor alpha and beta specific agonists regulate expression of synaptic proteins in rat hippocampus. Brain Res 2009;1290:1-11.

137 Ma X-M, Huang J-P, Kim E-J, Zhu Q, Kuchel GA, Mains RE, et al: Kalirin-7, an important component of excitatory synapses, is regulated by estradiol in hippocampal neurons. Hippocampus 2011;21:661-677.
Hormones and Neurotransmitters in OCD
Neuroendocrinology 2017;105:1-16 DOI: $10.1159 / 000453664$ 
138 Feng X-Q, Dong Y, Fu Y-M, Zhu Y-H, Sun J-L, Wang Z, et al: Progesterone inhibition of dopamine-induced increase in frequency of spontaneous excitatory postsynaptic currents in rat prelimbic cortical neurons. Neuropharmacology 2004;46:211-222.

139 Bethea CL, Reddy AP: Ovarian steroids increase glutamatergic related gene expression in serotonin neurons of macaques. Mol Cell Neurosci 2012;49:251-262.

140 El-Bakri NK, Islam A, Zhu S, Elhassan A, Mohammed A, Winblad B, et al: Effects of estrogen and progesterone treatment on rat hippocampal NMDA receptors: relationship to Morris water maze performance. J Cell Mol Med 2004;8:537-544.

141 Son I, Shin H-J, Ryu J-H, Kim H-K, Do S-H, Zuo Z: Progesterone increases the activity of glutamate transporter type 3 expressed in Xenopus oocytes. Eur J Pharmacol 2013;715: 414-419.

142 Mitrovic AD, Maddison JE, Johnston GAR: Influence of the oestrous cycle on L-glutamate and L-aspartate transport in rat brain synaptosomes. Neurochem Int 1999;34: 101-108.
143 Leckman JF, Goodman WK, North WG, Chappell PB, Price LH, Pauls DL, et al: Elevated cerebrospinal fluid levels of oxytocin in obsessive-compulsive disorder. Comparison with Tourette's syndrome and healthy controls. Arch Gen Psychiatry 1994;51:782792.

144 Marazziti D, Baroni S, Giannaccini G, Catena-Dell'Osso M, Piccinni A, Massimetti $\mathrm{G}$, et al: Plasma oxytocin levels in untreated adult obsessive-compulsive disorder patients. Neuropsychobiology 2015;72:74-80.

145 Leckman JF, Goodman WK, North WG, Chappell PB, Price LH, Pauls DL, et al: The role of central oxytocin in obsessive compulsive disorder and related normal behavior. Psychoneuroendocrinology 1994; 19:723749.

146 Humble MB, Uvnäs-Moberg K, Engström I, Bejerot S: Plasma oxytocin changes and antiobsessive response during serotonin reuptake inhibitor treatment: a placebo controlled study. BMC Psychiatry 2013;13:344.

147 Altemus M, Jacobson KR, Debellis M, Kling M, Pigott T, Murphy DL, et al: Normal CSF oxytocin and NPY levels in OCD. Biol Psychiatry 1999;45:931-933.
148 den Boer JA, Westenberg HG: Oxytocin in obsessive compulsive disorder. Peptides 1992;13:1083-1085.

149 Yoshida M, Takayanagi Y, Inoue K, Kimura T, Young LJ, Onaka T, et al: Evidence that oxytocin exerts anxiolytic effects via oxytocin receptor expressed in serotonergic neurons in mice. J Neurosci 2009;29:2259-2271.

150 Kaya V, Uguz F, Sahingoz M, Gezginc K: Pregnancy-onset obsessive-compulsive disorder: clinical features, comorbidity, and associated factors. Klin Psikofarmakol Bul 2015;25:248-258.

151 Labad J, Menchón JM, Alonso P, Segalàs C Jiménez S, Vallejo J: Female reproductive cycle and obsessive-compulsive disorder. J Clin Psychiatry 2005;66:428-435.

152 Kerlan V, Nahoul K, Le Martelot MT, Bervocivi JP: Longitudinal study of maternal plasma bioavailable testosterone and androstanediol glucuronide levels during pregnancy. Clin Endocrinol (Oxf) 1994;40:263267.

153 Meulenberg PM, Hofman JA: Maternal testosterone and fetal sex. J Steroid Biochem Mol Biol 1991;39:51-54. 